IBIMA Publishing

Journal of Eastern Europe Research in Business and Economics

http://www.ibimapublishing.com/journals/JEERBE/jeerbe.html

Vol. 2016 (2016), Article ID 420774, 12 pages

DOI: $10.5171 / 2016.420774$

Research Article

\title{
Catching-up Processes in Central European Countries
}

\author{
Elena Fifeková and Andrea Vondrová \\ University of Economics in Bratislava, Faculty of National Economy, Department of Economic Policy, \\ Bratislava, Slovakia
}

Correspondence should be addressed to: Andrea Vondrová; andrea.vondrova@euba.sk

Received date: 23 February 2015; Accepted date: 16 June 2015; published date: 7 September 2016

Academic Editor: Eugenia lancu

Copyright (C 2016. Elena Fifeková and Andrea Vondrová. Distributed under Creative Commons CCBY 4.0

\begin{abstract}
This paper evaluates the progress of the countries of Central Europe in their convergence efforts with the original Member States of the European Union. It examines the impact of the integration of Central European countries into the EU on their growth and catching-up process. It evaluates the creation of conditions for narrowing the performance gap between the countries of Central Europe and the old Member States, the rate of catch-up process and factors that have the greatest impact on the real convergence of Central Europe to the EU-15 average. Attention is mainly paid to the assessment of the upward impact of the overall productivity of factors. There are also identified bottlenecks in the development process of the evaluated countries.
\end{abstract}

Keywords: transformation process, catch-up effect, real convergence

\section{Introduction}

The preparation of Central European countries for the membership in the European Union and entry into the EU brought significant growth stimulus. The liberalization of capital and financial accounts of these countries increases their financial integration. The implementation of real convergence criteria and the subsequent accession of the V4 countries into the European Union meant increased confidence at the economic development of a region's attractiveness for foreign investors.Strong growth in Central European countries was supported by political stability, structural reforms, investments, and the arrival of foreign direct investors in the region (Reiner Winkler, 2009). These facts have a positive impact on the growth of productivity factors, which in the pre-crisis period was an important accelerator of economic growth. Despite the fact that all countries disposed with huge potential for growth,

Cite this Article as: Elena Fifeková and Andrea Vondrová (2016)," Catching-up Processes in Central European Countries ", Journal of Eastern Europe Research in Business and Economics , Vol. 2016 (2016), Article ID 420774, DOI: 10.5171/2016.420774 
which indicated the possibility for narrowing the performance gap with the original member countries in a relatively short timeframe, the economic development of individual countries of central Europe takes place in recent years in a differentiated manner, what affects their level of economic catch up process. The current period, which brings the accumulation of economic and political problems, enhances the need to examine options that would increase economic growth and improve the characteristics of the socio-economic development.

\section{The basic framework of the integration of the transforming countries in the European Union}

The transformation of Central Europe meant not only the creation of conditions for the change of the coordination mechanism but also the progress towards their integration ambitions. For this purpose, the EU created conditions that allow the expansion of those countries. Association agreement formed the basic framework between the EU and individual countries. The decision to expand the EU15 by the new Member States was adopted at the European Council in Copenhagen in December 2002. In accordance with the conclusions of the meeting in 1993, the pre-accession process officially started with the invitation to apply for membership of the Union. There have been established criteria (Copenhagen real convergence criteria) that candidate countries had to fulfill in order to become EU Member States. Their purpose was primarily to accelerate systemic and institutional changes in transition economies towards normal market economies.

The real convergence criteria should also create conditions where the enlargement of the EU will not slow down the momentum of European integration. „Copenhagen criteria clearly set out the rules of the game, firmly anchoring conditionality in the accession process. The political criteria required new Member States to ensure stability of institutions guaranteeing democracy, the rule of law, human rights, respect for and protection of minorities. The economic criteria called for the existence of a functioning market economy as well as the capacity to cope with competitive pressure and market forces within the Union"(Füle, 2013, s. 9).

Their successful management should have been the starting point for the sustainability of nominal convergence process after accession to the $\mathrm{EU}^{1}$, because at this time it was assumed that these countries after joining the EU will be interested in membership in EMU (the status of non-membership was not considered). Pre-accession strategy for the integration of candidate countries to the EU was reinforced in 1994 by adopting the Pre-accession strategy for the enlargement of the European Union. At the same time there have been adopted principles of providing financial assistance to the associated countries „White Paper: Preparation of the Associated Countries of Central and Eastern Europe for Integration into the Internal Market of the Union"(adopted in 1995), which set the framework for the candidate countries in their accession process. During the 90s the associated countries applied for the admission to the EU. The EU launched negotiations with the first group of candidate countries in 1998.

The implementation of real Copenhagen convergence criteria meant for Central European countries important progress in the area of the conditions for a functioning market economy as well as it helped to increase their competitiveness. In terms of acceleration of real convergence a major role has played the ability of transition countries to create a favorable environment for foreign investment and the speed with which the transition economies during the pre-accession process align with the requirement of openness of international capital movements (Kalotai, 2004). In accordance with Article 56 of the EU Treaty, the 
European Commission with the countries of Central and Eastern Europe created a timetable for the gradual liberalization of capital flows. The approach of individual Central European countries to the speed of the liberalization of capital movements was very different. While the Czech Republic has liberalized most of the capital transactions since 1995, Hungary, Poland, Slovakia and Slovenia had released their capital transaction steadily until joining the EU. Attitudes towards the privatization of state assets has also crucial role in extent of FDI inflows into the transition economies (Jensen, 2006). While for example Hungary preferred the privatization through direct sales to foreign investors, in several countries maintaining ownership of domestic entities has been the preferred approach (e.g. The Slovak law of strategic companies in the nineties eliminated the possibility of privatization of strategic companies by foreign bidders).

After the EU countries have adopted national reform programs (2005) aimed at strengthening competitiveness, the National Reform Programs have identified key challenges that should support macroeconomic stability; improve the business climate and quality of knowledgebased changes. By their very nature, they have been aimed at promoting knowledgebased activities, especially for promoting science, development, research and education.

\section{Growth and catching up}

The descriptive view of the development of Central European countries since their accession to the EU declares the progress in improvement of economic strength, economic performance, economic openness, and other parameters.

Central European countries managed over the past ten years to nearly double their share of created GDP by the European Union (Table 1). The average real GDP growth of Central European countries during the period was above the growth rate attained by the EU15, whilst the strongest economic growth has been achieved in the period until the economic crisis (in the period 2004-2008, the growth rate of their real GDP was nearly half times higher than the growth rate achieved by the old Member States).

The main reason for the above-average growth in the countries of Central Europe was the implementation of several economic reforms in order to comply with the convergence criteria and also the possibility of funding from the EU funds. The fulfillment of the convergence criteria and the improvement of conditions for mobility of capital made the region of Central Europe attractive for investors and an opened space for the increased mobility of capital into the region. 
Table 1: Economic growth and position of Central European countries within the EU 28

\begin{tabular}{|l|r|r|r|r|r|r|l|}
\hline \multirow{2}{*}{\begin{tabular}{l} 
Country \\
\cline { 2 - 8 }
\end{tabular}} & \multicolumn{3}{|c|}{ Share of nominal GDP EU28 } & \multicolumn{5}{c|}{ Average real GDP growth } \\
\cline { 2 - 8 } & 1995 & 2004 & 2014 & $\begin{array}{l}1995- \\
2014\end{array}$ & $\begin{array}{l}1995- \\
2003\end{array}$ & $\begin{array}{l}2004- \\
2008\end{array}$ & $\begin{array}{l}2009- \\
2014\end{array}$ \\
\hline EU28 & 100 & 100 & 100 & 1,54 & 2,14 & 1,80 & 0,78 \\
\hline SE & 3,04 & 4,05 & 5,62 & $2,96^{* *}$ & $2,76^{* *}$ & 3,99 & 1,79 \\
\hline V4 & 2,83 & 3,74 & 5,08 & $3,00^{* *}$ & $2,74^{* *}$ & 3,99 & 1,79 \\
\hline $\begin{array}{c}\text { Czech } \\
\text { republic }\end{array}$ & 0,63 & 0,87 & 1,11 & 2,15 & 1,51 & 4,28 & 0,79 \\
\hline Hungary & 0,48 & 0,75 & 0,75 & 2,03 & 2,57 & 1,91 & 1,03 \\
\hline Poland & 1,49 & 1,86 & 2,96 & 3,83 & 3,26 & 4,14 & 2,52 \\
\hline Slovakia & 0,21 & 0,32 & 0,54 & $3,40^{* *}$ & $2,61^{* *}$ & 6,12 & 2,15 \\
\hline Slovenia & 0,22 & 0,25 & 0,27 & 2,36 & 3,11 & 3,95 & 0,12 \\
\hline
\end{tabular}

*constant prices of 2010, ${ }^{* *}$ years 1997-2003, 1997-2014

Source: Eurostat, own calculations.

The European Commission (2009) estimated in its study that the preparation for accession and the actual accession of the new member states to the EU increased in the 2000-2008 economic growth at an average $13 / 4 \%$, while an important factor of referred influence has been considered the current improvement of macroeconomic and institutional framework, restructuring economies and increase in the intensity of technological catching up. An important role in the economic growth of Central Europe plays also an upward trend of the world economy, which is in the recovery phase, with the result that foreign demand acted in most countries as a strong upward momentum.

The warning sign of economic development was mainly between 2007 and 2008 high positive output gap in all surveyed countries (Table 2), which implied that the acceleration of economic growth is cyclical and in long-term difficult to sustain (overheating of individual economies has created pressure on the worsening of external economic balance parameters in each country).

The economic crisis has disproved the relationship of the real and potential output, and at the present time, all rated countries are below their production possibilities. Despite the improvement in the development of real output in the postcrisis period, individual countries have problems with the conclusion of the negative output gap. The most significant distance from the production frontier has currently the Slovak Republic. 
Table 2 : Output gap and external economic balance in the countries of Central Europe

\begin{tabular}{|l|c|c|c|c|c|c|c|c|c|c|c|c|}
\hline & \multicolumn{9}{|c|}{ Output gap (\% of potential product at } & \multicolumn{5}{c|}{ Current account balance (\% of GDP) } \\
\cline { 2 - 14 } & 2004 & 2005 & 2006 & 2007 & 8 & 2013 & 2004 & 2005 & 2006 & 2007 & 2008 & 2014 \\
\hline EU28 & 0,2 & 0,22 & 1,64 & 2,79 & 1,73 & $-2,43$ & 0,49 & 0,04 & $-0,22$ & $-0,41$ & $-0,96$ & 1,43 \\
\hline $\begin{array}{l}\text { Czech } \\
\text { republic }\end{array}$ & 0,81 & 2,49 & 4,98 & 5,90 & 4,62 & $-1,92$ & $-5,05$ & $-0,93$ & $-2,11$ & $-4,39$ & $-2,12$ & $-0,20$ \\
\hline Hungary & 2,28 & 3,32 & 4,58 & 2,94 & 2,38 & $-0,70$ & $-8,43$ & $-7,48$ & $-7,41$ & $-7,28$ & $-7,40$ & 2,47 \\
\hline Poland & $-2,92$ & $-2,56$ & 0,13 & 3,33 & 3,19 & $-0,79$ & $-5,24$ & $-2,38$ & $-3,85$ & $-6,23$ & $-6,60$ & $-1,54$ \\
\hline Slovakia & $-0,51$ & 0,69 & 3,08 & 7,58 & 7,52 & $-2,65$ & $-7,85$ & $-8,46$ & $-7,84$ & $-5,32$ & $-6,25$ & 1,90 \\
\hline Slovenia & 1,18 & 1,74 & 3,69 & 6,99 & 6,82 & $-2,56$ & $-2,58$ & $-1,68$ & $-1,68$ & $-4,03$ & $-5,25$ & 5,89 \\
\hline
\end{tabular}

Source: Ameco, IMF, World Economic Outlook Database, October 2014.

The year 2009 brought not only the economic decline for most of the Central European countries, but also pointed to their poor ability to sustain the achieved growth dynamics. Despite the fact that the economic crisis has reduced the previously prevailing optimistic expectations about the relatively rapid settlement of economic level of the original Member countries and the countries of Central Europe, Central European countries achieved in the current period $70 \%$ of the economic performance of the old Member States.
If we look at the individual countries of Central Europe, we can see that the rate of catching up the process ${ }^{2}$ reached in the post-crisis period is a very differentiated value. While in Poland and Hungary catching up process has been accelerated, in Slovakia and the Czech Republic, the process of catching up slowed down and Slovenia throughout the post-crisis period shows divergent trends (Table 3 ). 
Table 3: the catch up rate of the Central European Countries with the EU15

\begin{tabular}{|l|c|c|c|c|}
\hline & $\mathbf{1 9 9 8 - 2 0 1 3}$ & $\mathbf{1 9 9 8 - 2 0 0 3}$ & $\mathbf{2 0 0 4 - 2 0 0 8}$ & $\mathbf{2 0 0 9 - 2 0 1 4}$ \\
\hline Czech Republic & $-2,00$ & $-0,94$ & $-3,82$ & $-1,90$ \\
\hline Hungary & $-2,12$ & $-3,00$ & $-1,19$ & $-2,33$ \\
\hline Poland & $-2,77$ & $-0,59$ & $-2,64$ & $-5,24$ \\
\hline Slovenia & $-1,61$ & $-3,18$ & $-6,51$ & 3,55 \\
\hline Slovakia & $-3,57$ & $-1,24$ & $-7,30$ & $-2,70$ \\
\hline
\end{tabular}

Source: AMEC0, own calculations.

The economic catch-up was affected by their initial economic level and economic performance (Figure 1), both in Central European countries as in the old Member States. While in 1995 relative economic performance of Poland $336.4 \%$ of the EU15 average) and Slovakia (40.3\% EU average) belonged among the lowest among the countries of Central Europe, both countries were able to narrow their performance gap in relation to the EU15 (in the case of Poland relative economic performance has increased by 27.4 percentage points and in Slovakia by 29.5 percentage points). The smallest shift in growth of relative performance was achieved by the Czech Republic (10.7 percentage points) and Slovenia (13.1 percentage points).

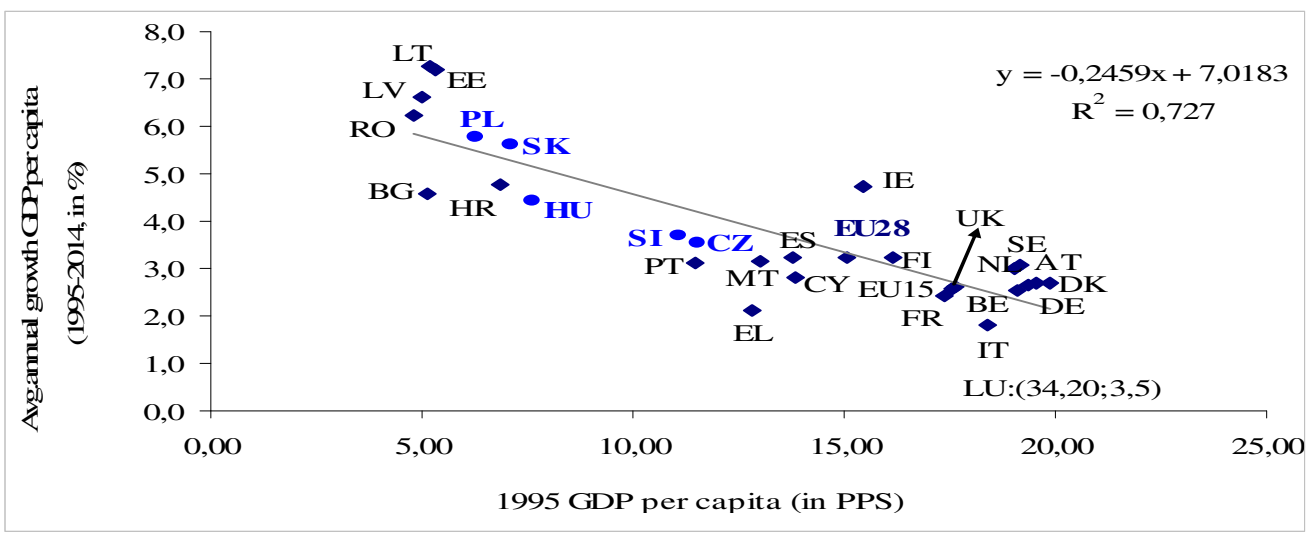

Figure 1: Economic growth and economic level in the European Union

Note: BE - Belgium, BG - Bulgaria, HR - Croatia, CY - Cyprus, CZ - Czech Republic, DK - Denmark, EE - Estonia, FI - Finland, FR - France, DE - Germany, EL - Greece, HU - Hungary, MT - Malta, NL - Netherlands, IE - Ireland, IT Italy, LT - Lithuania, LU - Luxembourg, ,LV - Latvia, PL -Poland, PT - Portugal, RO - Romania, SI - Slovenia, SK Slovak Republic, ES - Spain, SE - Sweden, UK - United Kingdom Source: AMECO, own calculations.

In terms of long-term economic growth, it is particularly important to monitor upward impact total factor productivity, since it provides long-term growth effects, represents a permanent change in the rate of accumulation and thus lasting change in the rate of economic growth. The growth effect of physical capital is the mediumterm. Accumulation in physical capital faces the law of diminishing returns, which means that by its treatment the growth of product per person at the end stopped at a 
new higher level. In long-term growth effects, growth rate is always higher (Baldwin, Wyplosz 2008). Total factor productivity as a growth factor reflects especially the impact of technological progress, the effects of research and development, the contribution of human resources development, institutional and organizational changes, but also the impact of the reallocation of factors between sectors, increasing returns to scale and the change in the rate of utilization factors (Hajek, 2005).

Several empirical studies indicate that convergence in the Central Europe was pulled by the growth of productivity factors (Arratibel et al. 2007 Morgese Bory set al. 2008). The acceleration capability has been enhanced by the presence of foreign direct investment, which also positively influenced the development of the other factors of long-term growth. FDI affected not only the amount of capital stock (through gross fixed capital formation), but positively influenced the growth of technological development of individual economies and increased productivity (Table 4). The presence of FDI in Central European countries led to the fact that the total net capital stock grew much faster than in the old EU Member States. After 2008, there was a moderation of capital in all countries except Poland. The presence of FDI was equally positively displayed in the development of the productivity of factors.

Table 4: Production factors' contribution to growth (average annual \% change in constant prices)

\begin{tabular}{|c|c|c|c|c|c|c|c|c|}
\hline & \multicolumn{4}{|c|}{ 1998-2014 } & \multicolumn{4}{|c|}{ 1998-2003 } \\
\hline & GDP & $\begin{array}{l}\text { capit } \\
\text { al } \\
\text { factor }\end{array}$ & $\begin{array}{l}\text { labor } \\
\text { factor }\end{array}$ & TFP & GDP & $\begin{array}{l}\text { capit } \\
\text { al } \\
\text { factor }\end{array}$ & $\begin{array}{l}\text { labor } \\
\text { factor }\end{array}$ & TFP \\
\hline EU15 & 1,24 & 0,64 & 0,36 & 0,24 & 2,37 & 0,8 & 0,92 & 0,65 \\
\hline Czech Republic & 2,73 & 0,98 & 0,21 & 1,54 & 2,44 & 1,06 & $-0,46$ & 1,84 \\
\hline Hungary & 1,78 & 1,04 & $-0,10$ & 0,84 & 3,93 & 1,18 & 0,53 & 2,21 \\
\hline Poland & 3,65 & 1,89 & 0,21 & 1,55 & 3,38 & 1,46 & $-1,14$ & 3,06 \\
\hline Slovenia & 3,98 & 1,29 & 0,22 & 2,46 & 3,80 & 1,18 & 0,58 & 2,04 \\
\hline \multirow[t]{3}{*}{ Slovakia } & 3,16 & 1,05 & 0,19 & 1,93 & 3,10 & 1,73 & $-0,28$ & 1,65 \\
\hline & \multicolumn{4}{|c|}{ 2004-2008 } & \multicolumn{4}{|c|}{ 2009-2014 } \\
\hline & GDP & $\begin{array}{l}\text { capit } \\
\text { al } \\
\text { factor }\end{array}$ & $\begin{array}{l}\text { labor } \\
\text { factor }\end{array}$ & TFP & GDP & $\begin{array}{l}\text { capit } \\
\text { al } \\
\text { factor }\end{array}$ & $\begin{array}{l}\text { labor } \\
\text { factor }\end{array}$ & TFP \\
\hline EU15 & 2,13 & 0,82 & 0,73 & 0,58 & $-0,05$ & 0,34 & $-0,25$ & $-0,13$ \\
\hline Czech Republic & 5,47 & 1,24 & 0,83 & 3,39 & $-0,09$ & 0,60 & $\begin{array}{l}-0,08 \\
\end{array}$ & $-0,60$ \\
\hline Hungary & 2,73 & 1,52 & $-0,24$ & 1,45 & $-0,54$ & 0,32 & $-0,04$ & $-0,82$ \\
\hline Poland & 5,42 & 1,90 & 1,61 & 1,90 & 2,63 & 2,29 & 0,00 & 0,34 \\
\hline Slovenia & 4,92 & 1,75 & 1,02 & 2,15 & $-2,03$ & 0,25 & $-1,29$ & $-1,00$ \\
\hline Slovakia & 7,26 & 2,05 & 0,83 & 4,37 & 1,21 & 0,43 & $-0,13$ & 0,91 \\
\hline
\end{tabular}

Capital, labour - weighted rate of growth, where the weights are labour and capital product elasticity.

Source: European commission (Ameco), Eurostat, GGDC, own calculations.

Table 4 shows that within the Central Europe countries the most significant upward impact of productivity of factors were reflected during the entire period in the Czech Republic and Slovakia. The warning sign for long-term economic growth is that in the post-crisis period there is a reduction in the growth of productivity factors. Compared to the precrisis period, the most significant decline was in the overall productivity of factors in the Czech Republic and Slovenia. In the 
post-crisis period, the aggregate productivity of factors acts upwardly only in Slovakia. The current decline in the overall productivity of factors raises the concern that the strong growth of the overall productivity of factors has been mostly triggered by transformation and is not a renewable source of convergence in the future.

Similarly, the labor factor negatively affected in the post-crisis period long-term growth. Given the fact that the structures of the economies of Central European countries have maintained a high proportion of capital-intensive industries, the growth of capital factor also positively affects the current period of the economic growth. However, in total in all production factors, a reduction in the upward impact can be observed.

As a consequence, the European Commission's projection assumes that it is necessary to revise the estimate of the potential output downwards (EC 2012). The projection of factors of economic growth assumes in that period a negative impact of employment development on GDP growth, mainly due to demographic developments, where the employment rate will be influenced mainly by the number of people of the population in the working age. From a regional perspective, in all surveyed countries will occur the alleviation of long-term growth rate of GDP in comparison to the pre-crisis development, and the strongest decline will be precisely in the new EU member states.

\section{Qualitative aspects of catching up}

Despite the positive efforts to increase the support of science, research and education, in the Central European countries it is their bottleneck. All the countries in the innovation activity are below the level of EU15. The gap in the innovation inputs is then reflected in the extent and quality of innovative products and determines the nature of competitiveness of each country.

To identify the position of Central Europe in the field of innovation and technological level, we used the assessment of competitiveness of countries that annually provides World Economic Forum (Figure 2). In the evaluation, the global competitiveness of innovative activity is assessed through the quality of the national innovation system, i.e. through the range of innovation, quality of scientific research institutions, the amount of expenditures on research and development, cooperation between universities and enterprises in research and development, the scope of contracts to high technology-intensive products, the availability of scientists and the extent of use of patents. Technological readiness evaluates a particular level of availability of the latest technologies, standards for technological absorption of enterprises, technology transfer through FDI, but also the level of use of broadband internet access, personal computers and the legislation that governs the use of information and communication technologies. 


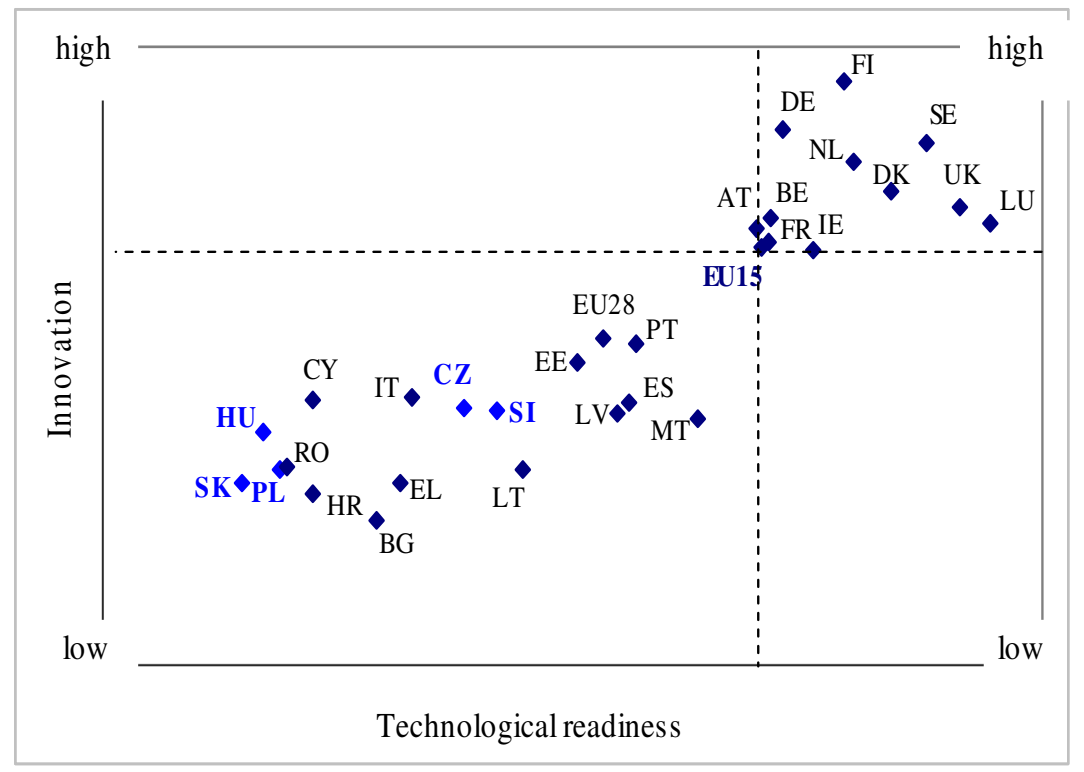

Figure 2: Innovation performance of the EU

As seen in Figure 2, the EU represents very heterogeneous grouping regarding the conditions for improving innovation performance. While the Scandinavian countries, Germany, Netherlands, France, Austria, Belgium and the United Kingdom have formed the conditions for the growth of innovation performance at a very high level, the countries of Central Europe failed to remove innovative lagging.

This fact is largely due to the fact that the countries of Central Europe in the field of improving innovation performance relied on a significant extent on technology transfer through FDI. This strategy, however, has its risks (e.g. foreign capital does not always bring only high technology, not always sufficiently proinnovatively stimulates the behavioral changes or that range of investment incentives prevents the fiscal stability of the economy and reduces the space for the promotion of domestic research and development, etc.). In this context, it should be kept in mind that in the countries of
Central Europe are placed standardized medium and high-tech activities often under the fragmentation of the value chain, which on the one hand reflect in an increased share of high technologyintensive industries in the structure of the economy but on the other hand significantly reduce pressure on the qualification demands of the industry, and ultimately do not create sufficient incentives to increase their own innovation performance.

Insufficient innovation performance did not create enough space to change the nature of competitive advantages. That is why in many transformed economies can be monitored the use of traditional factor of competitive advantages and lowers the support of qualitative growth changes. on a larger scale than in the EU15 A different approach of supporting the competitiveness has the effect that while in the old EU Member States, the competitive ability and performance of the economy is advanced in particular by supporting the 
development of knowledge-based activities and factors, many transformed economies have their economic growth and competitive advantage based on factors more typical for an industrial development (Fifeková et al., 2013).

\section{Conclusions}

High growth dynamics of Central European countries, which to a considerable extent exceeded the EU-15 average, has led to narrowing the performance gap between the groups of countries.

Among countries with the highest rate of real economic growth indisputably belonged Poland and Slovakia. The economic crisis, which in 2009 affected all Central European countries except Poland, moderated the speed of convergence. After this year, there was a decrease in the growth dynamics of individual countries, catching-up process was slowed down. Narrowing the performance gap between individual countries and the $\mathrm{EU}$ has a differentiated course. The process of convergence of the Czech Republic, Hungary, Poland and Slovakia continues at a slower pace than in the pre-crisis period, Slovenia in the current period reported divergence to the EU15.

In terms of factors in long-term growth, the most significant benefit during the entire period provided the aggregate productivity of factors and factor capital. The current decline in the overall productivity of factors raises the concern that the strong growth of productivity of factors in the countries of Central Europe was mainly due to the transformation and may not be a renewable source of convergence in the future.

The extent to which the countries of Central Europe would be able to create the conditions for narrowing the performance gap in a relatively short period of time depends primarily on their efforts to create conditions for economic growth, which should exceed the economic growth in the EU at least by one percentage point.
The recent slowdown in economic growth in the European space limits economic growth in Central Europe and enhances pressure on the quality parameters of their economic development.

It is therefore necessary, that catching-up countries would ensure the permanence of pro-growth action of each factor in the area of creation of GDP, especially for the growth of productivity factor since it provides long-term growth effects. Attention should be directed primarily at supporting its own research and development, innovation capabilities and knowledge-based activities.

\section{Acknowledgement}

This article is a part of the research project VEGA 1/0313/14: Relation between efficiency and equity - implications for economic policy.

\section{Notes}

The Global Competitiveness Report 2014-2015. World Economic Forum 2014.

Copenhagen real convergence criteria: The criteria have been set by the European Council in Copenhagen in 1993.

The economic performance of countries in $\%$ of the average performance of the EU15

The Recovery Phase: The option to differentiate the impact of internal and external factors on the growth is considered rather hypothetical, because the increasing foreign demand may affect upward, but only if the supply of the country is able to respond to this demand. A flexible choice is eventually affected by the quality of economic policy measures.

1The catch- up rate is defined as the average percentual change of the performance gap among particular countries. 
$M=100 \frac{\Delta\left(Y_{i t}-Y_{t}^{*}\right)}{\left(Y_{i t-1}-Y_{t-1}^{*}\right)}$

Where:

M- catch up rate

Yt* - average Yt value for EU15

$\Delta$ - the absolute variation between $\mathrm{t}$ and $\mathrm{t}$ -

1 , where $\mathrm{Yt}^{*}$ is weighted average of EU15

\section{References}

1. Arratibel, O., Heinz, F., Martin. R., Przybyla, M., Rawdanowicz, I., Serafini, R. and Zumer, T. (2007), "Determinants of Growth in the Central and Eastern European EU Member States a Production Finction Approach,' ECB Occasional Paper Series No. 61. [Online]. [Retrieved January18 January, 2015], https://www.ecb.europa.eu/pub/pdf/scpo ps/ecbocp61.pdf?f431c86b389e0f7e42ed1 $990150 \mathrm{a} 60 \mathrm{e} 1$.

2. Baldwin, R. and Wyplosz, Ch.(2008). Ekonomie evropské integrace, Grada Publishing, Praha.

3. European Commission (1994), "Preaccession strategy for enlargement of the European Union,' [Online], [Retrieved January 22, 2015], http://www.europarl.europa.eu/enlargem ent/briefings/24a1_en.htm

4. European Commission (1995), "White Paper: Preparation of the Associated Countries of Central and Eastern Europe for Integration into the Internal Market of the Union,' [Online], [Retrieved January 20, 2015],

http://aei.pitt.edu/1120/1/east_enlarg_wp _COM_95_163.pdf.

5. European Commission (2004), "The EU economy: 2004 review,' DirectorateGeneral for Economic and Financial Affairs,' [Online], [Retrieved January 22, 2015], http://ec.europa.eu/economy_finance/pub lications/publication451_en.pdf.

6. European Commission (2009), 'Five years of an enlarged EU: Economic achievements and challenges'.
Luxembourg: Office for Official Publications of the European Communities.

7. European Commission (2012), "The 2012 Ageing Report. Economic and budgetary projections for the $27 \mathrm{EU}$ Member States (2010-2060),' [Online]. [Retrieved January 5, 2015], http://ec.europa.eu/economy_finance/pub lications/european_economy/2012/pdf/ee -2012-2_en.pdf>.

8. Fifeková, E. et al. (2013). Ekonomický rast a jeho kvalita, Vydavatel'stvo EKONÓM, Bratislava.

9. Füle, Š. (2013), "Copenhagen Criteria the Backbone of EU Enlargement. 20 Years that Changed Europe. The Copenhagen Criteria and the Enlargement of the European Union,' Conference Report. [Online], [Retrieved January 10, 2015], http://um.dk/da/ /media/UM/Danishsite/Documents/Udenrigspolitik/Nyhederogpublikationer $/ 20 \% 20$ Years $\% 20$ that $\% 20 \mathrm{C}$ hanged\%20Europe_UM.pdf

10.Hájek, M. (2005), "Ekonomický růst a souhrnná produktivita faktorů V České republice v letech 1992-2004,' Working paper CES VŠEM. [Online], [Retrieved January 5, 2015], http://www.vsem.cz/data/data/cessoubory/working-paper/gf_WPNoV.pdf

11.Jensen, C. (2006), 'Foreign Direct Investment and Economic Transition: Panacea or Pain Killer? '' Europe-Asia Studies, vol. 58, no. 6, 881-902.

12.Kalotay, K. (2004), 'The European Flying Geese: New FDI patterns for the Old Continent? ,' Research in International Business and Finance, 18, 27-49.

13.Morgese Borys, M., Polgar, E.K. and Zlate, A. (2008) ), "Real Convergence in Central, Eastern and South-Eastern Europe,' ECB Occasional Paper Series. [Online], [Retrieved January 10, 2015], https://www.ecb.europa.eu/pub/pdf/scpo ps/ecbocp86.pdf?7e66edb3d4f24f7d3462 18e122031c1b 
14.Reiner, M. and Winkler, A. (2009), Real convergence in Central, Eastern and SouthEastern Europe. Palgrave Macmillan.

15.Schwab, K. (2014) , "The Global Competitiveness Report 2014 - 2015,'

World Economic Forum. [Online],
[Retrieved January 10, 2015], http://www.weforum.org/issues/globalcompetitiveness

16.Database: Eurostat, Ameco, GGDC 